Е.Е. Звонова

\title{
РЕЛИГИОЗНО-МИСТИЧЕСКИЕ ВЗГЛЯДЫ ЦИОЛКОВСКОГО И ЧИЖЕВСКОГО В СВЕТЕ ПРЕДСТАВЛЕНИЙ О КОСМИЧЕСКОМ СОЗНАНИИ И КОНЦЕПЦИИ КОСМИЧЕСКОЙ ИГРЫ
}

\begin{abstract}
Аннотация. Предметом настоящей работы являются религиозные и мистические прозрения Чижевского и Циолковского в свете представлений о космическом сознании, понимаемом согласно Бёкку, а также концепции космической игры. Реконструируются соответствующие «еретические» идеи калужских космистов. Приводится ряд аргументов, подтверждающих гипотезу о том, что друзья-мыслители обладали космическим сознанием. Обоснованность доводов, говорящих в пользу предположения о причастности Циолковского и Чижевского к космическому сознанию, достигается путем детального анализа феноменологии данного явления, а также личных качеств и творчества Константина Эдуардовича и Александра Леонидовича. Признание основателей космического естествознания носителями высшей формы сознания позволяет по-новому оценить основание их религиозно-мистических воззрений, рассмотреть таковые в контексте концепции космической игры и наталкивает на мысль о пророческом призвании Циолковского и Чижевского.

При написании настоящей работы были использованы следующие методы: анализ литературы, сравнение, анализ, синтез, индукция, дедукция, обобщение.

Научную новизну статьи составляет попытка установить невербальный источник религиозных и мистических аспектов творчества Циолковского и Чижевского и истолковать таковые в свете представлений об этом источнике. Основные выводы, к которым приходит автор в процессе исследования, заключаются в том, что гипотеза о причастности Константина Эдуардовича и Александра Леонидовича к космическому сознанию с высокой долей вероятности справедлива, многие религиозно-мистические идеи калужских космистов имеют своим основанием соответствующее состояние и могут получить любопытную интерпретацию в контексте концепции космической игры, а в Циолковском и Чижевском можно предположить вестников космической эволюции.
\end{abstract}

Ключевые слова: религия, мистика, эзотерика, космическое сознание, космическая игра, космическая эволючия, космизм, Циолковский, Чижевский, Бёкк.

Ц

иолковский и Чижевский... Судьбы этих двух замечательных ученых и мыслителей-космистов были тесно переплетены между собой, и имя одного неизменно сопутствует имени другого на страницах книг, в научных и философских дискуссиях.

Невольно вспоминается эпизод из бессмертного романа Булгакова «Мастер и Маргарита», в котором Иешуа Га-Ноцри и Понтий Пилат, беседуя, идут вверх по лунной дорожке: «Мы теперь будем всегда вместе, - говорил ему во сне оборванный философ-бродяга, неизвестно каким образом вставший на дороге всадника с золотым копьем. Раз один - то, значит, тут же и другой! Помянут меня, - сейчас же помянут и тебя! Меня — подки- дыша, сына неизвестных родителей, и тебя - сына короля-звездочёта и дочери мельника, красавицы Пилы» ${ }^{1}$. Так бы и Циолковский мог сказать Чижевскому, разве что себя назвать при этом не подкидышем, а, скажем, «самоучкой чистой крови», удостоив Александра Леонидовича титула пусть не сына короля-звездочёта, но, например, «Леонардо да Винчи XX века».

Действительно, очень легко представить себе двух космистов преодолевающими притяжение Земли и устремляющимися ввысь, прочь от неё,

Булгаков M.A. Мастер и Маргарита. (URL: http://www. loveread.ec/read_book.php?id=1527\&p=100. (дата обращения: 20.02.214)) 
в Бесконечность и Вечность. И в Вечности этой у них, по-видимому, окажется достаточно времени, чтобы поспорить «о чём-то очень сложном и важном» ${ }^{2}$. Пусть они друзья-единомышленники, но спор их наверняка будет «особенно интересен и нескончаем» ${ }^{3}$. И, конечно же, в Вечности мыслители не забудут о том, что «трусость, несомненно, один из самых страшных пороков» ${ }^{4}$ (если не самый страшный), как не забывали они того и при земной жизни...

Впрочем, нам не следует судить о том, что будет «там», от подобного философского тщеславия предостерегал ещё великий Кант. Лучше говорить о случавшемся в нашем мире. Тем более что и за время своего пребывания в нём Циолковский и Чижевский успели поспорить, пообсуждать друг с другом свои взгляды, подчас, вероятно, забывая, кому из них двоих они, собственно, принадлежат, приписывая их собеседнику...

В настоящей статье мне хотелось рассмотреть религиозно-мистические прозрения Константина Эдуардовича и Александра Леонидовича в свете представлений о космическом сознании и связанной с ними концепции космической игры. Будет высказано предположение о причастности Циолковского и Чижевского к космическому сознанию, понимаемому согласно Бёкку - канадскому исследователю, открывшему и описавшему данный феномен, а также приведены аргументы в пользу справедливости этого предположения. Признание калужских друзей-мыслителей носителями космического сознания проливает дополнительный свет на их религиозные и мистические представления, позволяет изучить таковые в необычном контексте космической игры.

Ценность данной работы обусловлена следующими соображениями. «Еретические» аспекты творчества Циолковского и Чижевского долгое время замалчивались, соответственно, пришло время обратить на них внимание. В частности, психологические и онтологические истоки отношения космистов к Абсолюту изучены недостаточно. Совместное же рассмотрение точек зрения Циолковского и Чижевского поможет глубже понять специфику каждой из них. Исследование обозначенных выше сюжетов, которые освещаются в настоящей

\footnotetext{
2 Там же.

Там же.

4 Там же.
}

статье, имеет значение для глубокого понимания идейного наследия русского космизма.

Великий Гёте писал:

Жил я в безумное время и общей судьбы не избегнул:

Стал неразумным и сам, как повелело оно 5 .

Циолковский и Чижевский также жили во время не во всём разумное, однако сохранили и разум, и веру в него. Другое дело, что многие детища их разума долгое время оставались в забвении, либо подвергались незаслуженной критике.

Пренебрежению и нападкам подверглись в первую очередь как раз те взгляды двух замечательных космистов, которые оценивались как религиозные или мистические, одним словом, «ненаучные» и не соответствовавшие «правильной» философии.

Так, о метафизических идеях Константина Эдуардовича в советской литературе отзывались подобным образом: «Характерно, что с 1931 года философских произведений Циолковский в свет не выпускал. Это имело очень глубокие основания. До революции Циолковскому, наряду со стихийным материализмом учёного-естествоиспытателя, были свойственны идеалистические воззрения, принимающие порой религиозно-мистическую окраску. Идеалистические взгляды развивались и в философских работах, изданных Циолковским после революции. Социологические воззрения Константина Эдуардовича в те годы были также сплошь и рядом ошибочными. В частности, он совершенно неправильно рисовал себе будущее общество. Но в дальнейшем Циолковский стал всё более сознавать неправильность своих философских представлений о природе и обществе. Он упорно работал над овладением единственно научным методом диалектического материализма, над изучением работ основоположников марксизма-ленинизма. В годы, о которых идёт речь, новое философское миросозерцание не успело ещё сложиться у Циолковского во вполне законченной форме, но со старыми взглядами он уже порвал. Этим и объясняется в первую очередь то, что он прекратил печатание ранее написанных философских произведений» ${ }^{6}$.

\footnotetext{
5 Гёте. Эпиграммы. Венеция 1790. Эпиграмма 54. (URL: http://coollib.net/b/197217/read. (дата обращения: 20.02.2014)).

6 Воробьёв Б. Н. Циолковский. М.: Молодая гвардия, 1940. C. 224-225.
} 
Как нетрудно догадаться, на самом деле Константин Эдуардович «прекратил печатание» философских работ потому, что (в лучшем случае) их попросту не напечатали бы, ведь «воззрений, принимающих порой религиозно-мистическую окраску» мыслитель не оставил.

Правда, Циолковский неоднократно подчёркивал в своих мировоззренческих трудах, что опирается на науку и придерживается материалистического монизма, призывал отрешиться для наилучшего его понимания от всего тёмного и неясного, открещивался от оккультизма, спиритизма и «тёмных философий», признавая даже Спинозу мистиком в сравнении с собой: «Если и опьяняет моё вино, то всё же оно натуральное. Моя цель - убедить без колебания издавать все мои сочинения» ${ }^{7}$. Однако шила в мешке не утаишь... ${ }^{8}$

Впрочем, даже из этого «оправдательного» отрывка видно, что потребность видеть свои работы напечатанными у Циолковского всё же была (кстати, «Монизм Вселенной», из которого заимствована вышеприведённая цитата, опубликован на средства автора в Калуге в 1925 г., т.е. после революции). Более того, в 1933 г., не имея возможности открыто высказывать свои метафизические идеи, Константин Эдуардович решается разослать наиболее важные с его точки зрения философские эссе своим самым надежным знакомым с просьбой сделать по одной машинописной копии и отправить напечатанное другим ${ }^{9}$.

Циолковский, согласно собственному признанию, был прежде всего мыслителем, техника являлась для него лишь средством, не целью ${ }^{10}$, именно

\footnotetext{
7 Циолковский К. Э. Монизм Вселенной // Космическая философия. М.: Сфера, 2004. С. 28.

8 Так, о специфике «трезвости» Циолковского красноречиво свидетельствует другой отрывок из его хроники событий собственной жизни, озаглавленной «Фатум, судьба, рок»: «(...) Увлекался ранее Евангелием. Придавал огромное значение Христу, хотя никогда не причислял его к сану богов. Я видел и в жизни своей судьбу, руководство высших сил. С чисто материальным взглядом на вещи мешалось что-то таинственное, вера в какие-то непостижимые силы, связанные с Христом и первопричиной. Я жаждал этого таинственного. Мне казалось, что оно меня может удержать от отчаяния и дать энергию. (...)». (Цитируется по: Дёмин В.Н. Циолковский. М.: Молодая гвардия, 2005. С. 5).

9 См. об этом подробнее: Дёмин В.Н. Циолковский. М.: Молодая гвардия, 2005.

10 Так, обращаясь к Чижевскому, Циолковский говорил: «Многие думают, что я хлопочу о ракете и беспокоюсь о её
}

поэтому он отчаянно пытался донести дорогие ему мировоззренческие идеи до людей и, несмотря на признание под конец жизни своих научных и технических заслуг, ощущал внутреннюю неудовлетворённость.

Показательно, что первой из разосланных Константином Эдуардовичем друзьям статей оказалось эссе «Есть ли Бог?». Правда, Бог в данной работе понимается в пантеистическом ключе, фактически отождествляется с космосом, со Вселенной, а душа человеческая описывается как «штучка», придумать которую побудило «незнание физиологии». Однако сам интерес к религиозной проблематике у Циолковского не ослабевал никогда.

Претендентами на звание Бога (или богов) у мыслителя оказывались сама эволюционирующая во взаимосвязи с порождённым ею разумом одушевлённая Вселенная, её причина, «высшие люди», а также другие безмерно превосходящие современного человека интеллектом и нравственностью существа (например, ангелы ${ }^{11}$ или президенты планет, галактик, «эфирных островов» (метагалактик) и т. п. вплоть до президента космоса).

Кроме того, Циолковский делился опытом общения с нечеловеческими разумными силами ${ }^{12}$ (в частности, признавался одному из своих посетителей в ежедневных беседах с ангелами), всю жизнь вдохновлялся образом «галилейского плотника», оставил после себя молитвы собственного сочинения, создал свою версию евангельских событий и даже жену выбрал, отчасти исходя из её глубокого понимания «благой вести».

Помимо христианских представлений, на учёного оказали несомненное влияние буддизм и индуизм, в особенности идеи о нирване и космических периодах, игре космоса, мировой воле, а также, возможно, теософия. Вопрос о влиянии по-

судьбе из-за самой ракеты. Это было бы грубейшей ошибкой. Ракеты для меня - только способ, только метод проникновения в глубину Космоса, но отнюдь не самоцель (...). Недоросшие до такого понимания вещей люди говорят о том, чего в действительности не существует, что делает меня каким-то однобоким техником, а не мыслителем». (Цитируется по: Дёмин В.Н. Циолковский. М.: Молодая гвардия, 2005. С. 6).

11 Ангелы понимались Циолковским в качестве высших существ, состоящих из менее плотной материи, нежели люди. Вообще дух ученый описывал как разреженную материю, стремясь оставаться монистом.

12 См. об этом, например: Дёмин В.Н. Циолковский. М.: Молодая гвардия, 2005; Ермолаева В.Е., Ермолаев И.А. Философия великой личности. М.: Север, 2007. 
следнего направления эзотерической мысли на Циолковского наименее исследован. Имеется ряд обстоятельств, подтверждающих данное влияние.

Так, в Калуге на протяжении двадцати лет (с перерывом с 1918 по 1922 годы из-за запрета властей) действовало теософское общество, информацию о лекциях и дискуссиях теософов регулярно предоставляли калужские газеты. Известно, что по крайней мере один из членов общества регулярно навещал Циолковского.

Исходя из анализа сочинений учёного, можно заключить, что ему была хорошо знакома книга Эдуарда Шюре «Великие посвящённые», причём само словосочетание, использованное в названии данного любимого эзотериками произведения, употреблялось в разговорах с единомышленниками как устоявшееся.

Следует также заметить, что в Калуге дважды издавался «Голос безмолвия» Блаватской, содержащий пересказ древнеиндийских притч и афоризмов, раскрывающих истины о путях совершенствования разума и обретения познания, а ангелы Циолковского во многом напоминают Махатм основательницы теософии. Константин Эдуардович мог пролистывать брошюру Блаватской «Закон причин и последствий, объясняющих человеческую судьбу» и сформировать свои представления о воле Вселенной под впечатлением от неё. Существует также вероятность опосредованного влияния идей Елены Петровны на Циолковского посредством трудов Камиля Фламмариона - одного из любимых авторов калужского мыслителя, бывшего лично знакомым с Блаватской и разделявшего её воззрения.

Впрочем, учитывая всё вышесказанное, не следует забывать, что сам учёный в своих сочинениях нигде не указывает прямо на своё знакомство с теософией.

Наконец, необходимо отметить солидарность Циолковского с канадским психиатром Ричардом Морисом Бёкком (1837-1902), описавшим феномен мистического состояния космического сознания, являющегося, по его мнению, предельным актуальным достижением эволюции человека. О взглядах Бёкка будет сказано подробно при рассмотрении предположения относительно одарённости Константина Эдуардовича и Александра Леонидовича космическим сознанием.

Казалось бы, религиозно-мистические воззрения космиста противоречивы, эклектичны и неортодоксальны с позиций, по крайней мере, христианства. Однако, быть может, не стоит торопиться с выводами.

Что касается противоречий, они могут быть расценены как диалектические в контексте представлений о космической игре, если мы признаем справедливость предположения о причастности Циолковского к космическому сознанию (нам ещё предстоит обратиться к аргументам в пользу данной гипотезы).

Неортодоксальность же (с христианской, в частности, православной точки зрения) соображений мыслителя по поводу религиозных сюжетов смягчается его указаниями на высшую причину космоса и приписываемыми ей характеристиками. Так, православный священник Александр Мень, являвшийся горячим поклонником и глубоким знатоком идей Константина Эдуардовича, счёл возможным совершить над могилой Циолковского обряд отпевания, что и было им сделано в 1966 г.

Обратимся теперь к «еретическим» взглядам Чижевского. Александр Леонидович не разделял богоискательских настроений своего старшего товарища. Он не оставил после себя работ, посвящённых непосредственно религиозной или мистической проблематике, редко можно найти достоверные сведения о его переживаниях, которые однозначно можно было бы оценить как прикосновение к сверхъестественному плану бытия. Соответственно, о Чижевском едва ли можно сказать так много абсолютно неоспоримого, как о Циолковском в соответствующем ключе.

Однако сам Александр Леонидович, посвятивший ряд исследований солнечно-земным связям и написавший немало поэтических строк, воспевающих одушевлённое и родственное ему «великолепное, державное Светило» (как, впрочем, и другие природные объекты, наделённые им сознанием), полушутя-полусерьёзно называл себя солнцепоклонником, а его недоброжелатели добавили к этому наименованию прозвища мракобеса и шарлатана.

Собственно, «солнцепоклонничество», «мракобесие» и «шарлатанство» Чижевского заключались, как известно, в следующем. В марте 1918 г. молодой учёный защищает на историко-филологическом факультете Московского университета докторскую диссертацию под названием «Исследование периодичности всемирно-исторического процесса». Её написанию предшествовали годы, на которые Чижевский, следуя совету Циолковского, «зарылся в статистику», изучая хроники, летопи- 


\section{Духовная реинкарнация}

си, исторические и медицинские труды, строя графики и кривые соответствия различных бедствий, бунтов, войн, эпидемий, революций циклам электромагнитных возмущений на Солнце. Результаты этих своих подвижнических изысканий, свидетельствующие о зависимости социальных и иных земных явлений от солнечной активности, Александр Леонидович и представил в диссертации, а затем в работе «Физические факторы исторического процесса (1924 г.).

Итак, выражаясь метафорически, молодой исследователь создаёт «новую астрологию», обосновав зависимость нашего земного бытия от космического влияния на новом уровне. Пионерские идеи Чижевского вызвали неоднозначную, но весьма бурную реакцию как в широких кругах, так и в научной среде. Учёного обвиняли в мистицизме, шарлатанстве, возрождении астрологии, контрреволюционных настроениях (революция есть выражение воли народных масс, а не продукт солнечной активности), требовали публичного отказа от собственных воззрений, покаяния, даже «осквернения» своего труда.

Чижевский обладал гениальной интуицией пантеиста, вдохновенно повествовал о ритмах и периодах вечно живого и эволюционирующего наряду и во взаимосвязи с человеческим разумом космоса, к которому испытывал сакральное отношение.

Было ли в воззрениях Александра Леонидовича нечто мистическое? Это весьма сложный вопрос, ибо нет общепринятой точки зрения на то, что такое мистика ${ }^{13}$.

Мистическим в самом общем смысле слова называется всё загадочное, «выходящее за рамки индивидуальной способности и понимания» (Шеллинг). Быть может, исследования Чижевского и выходили за рамки способностей и понимания его оппонентов, однако даёт ли это веский повод считать его мистиком?

В духовном смысле мистикой можно именовать восприятие и разумение мира как таинства, «живое прикосновение к тайне» (Бердяев), базирующееся на опыте переживания единства с Абсолютом непосредственное созерцание тайны, причём данный опыт обладает рядом характеристик, главные из которых - его целостность и неизре-

13 См. по этому поводу, например: Философия: Энциклопедический словарь / под ред. А.А. Ивина. М.: Гардарики, 2004. (URL: http://www.fidel-kastro.ru/filosofy/ihtik_ivin_slovar.htm. (дата обращения: 20.02.2014)). ченность. По-видимому, руководствуясь подобным определением, Чижевского опять-таки можно записать в мистики, но на сей раз содержание определения не столь сильно противоречит интуиции и здравому смыслу.

Действительно, даже научные труды Александра Леонидовича написанные прекрасным, образным языком, порождают ощущение «живого прикосновения к тайне», а также целостности Вселенной и неразрывной связи микро- и макрокосма.

Что касается поэтических произведений Чижевского, на мой взгляд, лучшим аргументом в пользу того, что в них отражено мистическое мировоззрение, является обращение к ним. В рамках настоящего исследования мы не можем сосредоточиться на анализе стихотворений Александра Леонидовича, однако я не в силах удержаться от того, чтобы не процитировать одно из них. Как известно, именно поэты способны словом выразить намёк на невыразимое.

о **
о беспредельном этом мире
В ночной тиши я размышлял,
А Шар Земной в живом эфире
Небесный свод круговращал.
О, как ничтожество земное
Язвило окрыленный дух!
О, как величие родное
Меня охватывало вдруг.
Непостижимое смятенье
Вне широты и долготы,
И свет, и головокруженье,
И воздух горней высоты.
И высота необычайно
Меня держала на весу,
И так была доступна тайна,
Что я весь мир в себе несу

Правда, в большинстве случаев (если не брать в расчёт поэзию) созерцание тайны для читателя работ Чижевского опосредовано не просто словом, но строгими доводами учёного и мыслителя, таблицами, графиками и т. п., однако откуда мы знаем,

14 Чижевский А.Л. Стихотворения / Вступ. ст., составл. и подг. текстов В.И. Безъязычного. М.: Современник, 1987. C. 143. 
было оно непосредственным у самого Александра Леонидовича или нет? Чижевский говорит о вполне изреченном, о фактах, однако почему их изложение вызывает ощущение неизреченного? Что первично в его случае - данное ощущение или факты? Вероятно, мы никогда не узнаем об этом точно, хотя нам ещё предстоит коснуться гипотезы о мистической природе сознания Александра Леонидовича в рамках настоящей статьи и привести ряд доводов, свидетельствующих в пользу её справедливости.

Тем не менее, несмотря на правдоподобность предположения о своеобразном мистицизме Чижевского, обвинения его хулителей следует признать несправедливыми.

Во-первых, мистицизм сам по себе ещё не есть мракобесие и шарлатанство.

Во-вторых, в научных работах Александр Леонидович прибегал к научным аргументам и методам без отсылок к неизреченным переживаниям, если же выводы, к которым он приходил, подтверждали некоторые представления, характерные для мистических учений, и вызывали соответствующие переживания, то это нельзя вменять в вину автору, иначе придётся признать, что учёный не должен оглашать научно установленных им закономерностей, если они коррелируют с определённой «ненаучной» картиной мира. По существу то, что различные способы постижения сущего на определённом этапе дают сходные результаты, должно расцениваться как естественное положение вещей, поскольку мир един.

Любопытно, что, подобно Циолковскому, Чижевский разделял идеи Бёкка о мистическом состоянии космического сознания, важнейшем (и пока предельном) рубеже, которого достигла эволюция человеческой психики. Ожидающее нас впереди рассмотрение аргументов в пользу того, что Александр Леонидович и Константин Эдуардович обладали космическим сознанием, также даёт веские основания отнести учёного-солнцепоклонника к мистикам.

Итак, подведём итоги.

Религиозные и мистические воззрения Циолковского и Чижевского значительно отличаются друг от друга. Если у Константина Эдуардовича имелся явный опыт визионерства, то у Александра Леонидовича он отсутствует. Циолковский интересовался вопросами религии и размышлял о кандидатах на роль Бога, Чижевский же не разделял богоискательских устремлений своего старшего товарища. На основателя современной космонавтики оказали глубокое влияние христианские, буддистские, индуистские, а также, возможно, теософские представления, отец же гелиобиологии по-новому осмыслил астрологию и порой (особенно в стихах) предстаёт почти язычником по духу, обращаясь к различным природным объектам - преимущественно к Солнцу, как к живым существам.

Однако при всей своей оригинальности Циолковский и Чижевский были схожи в отношении пантеистических интуиций, способности видеть в Мироздании сакральную тайну, а также интереса к изысканиям Бёкка о мистическом феномене космического сознания, который калужские мыслители, безусловно, признавали имеющим место быть в реальности.

Размышляя о сходстве взглядов Константина Эдуардовича и Александра Леонидовича, задумываешься о его характере и причинах. Собственно, формально у друзей-мыслителей не так много общих воззрений, касающихся мистики и религии. Однако буква мертвит, а дух животворит. И за различными конструкциями двух космистов угадывается нечто общее и существенное. При попытке обозначить это общее приходишь к выводу, что, по-видимому, таковым является сознание космоса. Как Спиноза смотрел на мир с точки зрения вечности, так Циолковский и Чижевский видели всё в космической перспективе.

Сознание же космоса полагается Бёкком главной чертой космического сознания. Вспоминая о том, что калужские мыслители были знакомы со взглядами канадского исследователя и разделяли их, невольно приходишь к предположению об их причастности к космическому сознанию. Если это предположение справедливо, религиозные и мистические аспекты творчества Циолковского и Чижевского могут быть рассмотрены в новом контексте, способствующем их глубокому пониманию. Соответственно, мне хотелось бы привести аргументы в пользу того, что Константин Эдуардович и Александр Леонидович обладали космическим сознанием.

Прежде всего, я считаю необходимым обратиться к описанию космического сознания, данному Бёкком (кстати, он, по собственному признанию, имел соответствующий мистический опыт), дабы при отсылках к указанному феномену читатель имел адекватное ему понятие.

Канадский исследователь полагает, что космическое сознание «есть форма сознания более 
высокая, чем та, которой обладает современный человек» ${ }^{15}$. Оно встречается лишь у немногих.

Бёкк выделяет три разновидности сознания: простое сознание, самосознание и космическое сознание. Простое сознание дает возможность сознавать своё тело и ориентироваться в окружающем мире. Им обладают, согласно Бёкку, высшие животные наряду с человеком. Следует учитывать, что с обретением нового уровня сознания низлежащие уровни остаются. Человек отличается от других млекопитающих наличием самосознания, наделяющего даром рефлексии, способностью делать собственные психические состояния объектом сознания. Космическое же сознание описывается канадским исследователем как настолько превосходящее самосознание, насколько последнее возвышается над простым сознанием.

Бёкк утверждает: «Главной чертой космического сознания, что отражено в его названии, является сознание космоса, т. е. жизни и порядка всей вселенной» ${ }^{16}$. Исследователь также отмечает, что внезапное снисхождение космического сознания сопровождается «субъективным светом». Человек переживает опыт интеллектуального озарения, преображающего его природу, и обретает интуитивный ум. Данное состояние характеризуется моральной элевацией, восторгом, а также ощущением бессмертия, говорящем не о грядущем, а об актуальном обладании вечной жизнью. Сама Вселенная воспринимается как нечто целостное, одушевленное, живущее ныне, присно и во веки веков, сознающее, а также тождественное Богу. Кроме того, обращённый чувствует себя более не принадлежащим собственной воле.

Бёкк подчеркивает «приблизительность» своего описания, признавая, что «лишь личный опыт или продолжительное изучение людей, переступивших порог этой новой жизни, может помочь нам ясно понять и ощутить, что это такое в действительности» ${ }^{17}$.

Впрочем, как замечает исследователь, выдающиеся поэты (многих из которых он причисляет к носителям космического сознания) в силах с помощью поэтического творчества намекнуть на содержание соответствующего невыразимого опыта.

15 Бёкк Р.М. Космическое сознание. Исследование эволюции человеческого разума / пер. с фр. М.: София, 2008. С. 8.

16 Там же. С. 10.

17 Там же. С. 10.
Бёкк полагает, что к обретению космического сознания при благоприятных обстоятельствах склонны преимущественно представители сильного пола, обладающие пылким стремлением к добру и правде и (как минимум) достаточно развитым интеллектом.

Несколько забегая вперёд, замечу следующее: канадский психиатр признаёт эволюцию человеческого сознания. Бёкк надеется на то, что в будущем практически все люди обретут космическое сознание. Между тем, идея о создании эволюцией всё более сложных типов сознания, наиболее совершенное из которых (человеческое) призвано возглавить её ход, придать ей активный характер, является генетической образующей чертой русского космизма ${ }^{18}$.

Итак, я попыталась изложить некоторые идеи Бёкка - те, что кажутся мне заслуживающими внимания в связи с тематикой настоящей статьи.

Прежде чем перейти к аргументам в пользу того, что Циолковский и Чижевский обладали космическим сознанием, мне хотелось бы в общих чертах осветить концепцию, которая зачастую упоминается в связи с соответствующим состоянием - концепцию космической игры. Это позволит нам далее рассмотреть религиозно-мистические взгляды космистов в необычном контексте.

Концепция космической игры, которую в наше время развивает, например, Станислав Гроф, имеет весьма древние корни, в частности, восходит к ведантистским представлениям о мире как игре Брахмана - Брахма-лиле. Основная идея концепции заключается в том, что Брахман (Космическое Сознание, Абсолют, Бог, Единое и т.п.), являющийся высшим идеальным началом, затевает игру, в процессе которой творит мир и индивидуальные сознания из самого себя. Иной субстанции, помимо Брахмана, не существует, и порождённые таковым объекты должны пройти долгий путь эволюции, прежде чем они наконец осознают свое субстанциальное тождество Абсолюту и сольются с Единым, после чего игра может возобновиться на новом уровне, проходя те же стадии: единство - разделение - воссоединение ${ }^{19}$. Собственно, опыт об-

\footnotetext{
18 См. Русский космизм: Антология философской мысли / сост. С.Г. Семенова, А.Г. Гачева. Вступ. ст.: С.Г. Гачева; предисл.: С.Г. Семенова; примеч.: А.Г. Гачева. М.: Педагогика: Пресс, 1993. С. 4.

19 По-видимому, устройством космической игры можно объяснить тот факт, что особенности низшей и высшей форм сознания сходны (невыделенность человека из окру-
} 
ретения космического сознания знаменует собой момент воссоединения.

Обратимся теперь к аргументам в пользу того, что Константин Эдуардович и Александр Леонидович обладали космическим сознанием.

Как мы помним, главной чертой описанного им состояния Бёкк считал сознание Космоса, проявляющееся в понимании жизни и порядка всей Вселенной. По моему убеждению, то, что Циолковский и Чижевский, мыслители-космисты и основоположники космического естествознания, отличались поразительным сознанием космоса в указанном выше смысле, абсолютно очевидно и едва ли требует специального обоснования. Пожалуй, целесообразнее приводить не столь очевидные доводы в пользу одарённости Циолковского и Чижевского космическим сознанием, при этом мы неизбежно вновь и вновь будем убеждаться в наличии у них сознания космоса.

Специфическим признаком исследуемого им мистического опыта Бёкк полагал световые видения. Иногда свет может исходить от огня, являющегося человеку, переживающему опыт космического сознания (например, случаи Моисея и Паскаля). В этом смысле показательно, что Циолковский сподобился одного из своих визионерских откровений, наблюдая закат. Правда, в данном случае свет был не «субъективным». Что касается Чижевского, он ощущал, по его собственному признанию, «неметафорический» огонь в состояниях творческого упоения, эмоциональной приподнятости, интеллектуального озарения ${ }^{20}$.

Космическое сознание зачастую бывает присуще выдающимся поэтам, и наилучшим образом намекнуть на этот невыразимый опыт вполне удается именно им. Поэтический талант Чижевского не подлежит сомнению, равно как и космический характер многих его стихотворений. Менее известно, что и Циолковский писал в юности стихи, к сожалению, не дошедшие до нас.

жающего мира, размывание пространственно-временных границ и т.п.). О точках зрения на отношения между человеком и миром, характеризующих различные эпохи и цивилизации, см.: Гуревич П.С. Философия человека. Ч. 1. М.: ИФ РАН, 1999; Гуревич П.С. Философия человека. Ч. 2. М.: ИФ РАН, 2001. Также см.: Гроф С. Космическая игра: Исследование рубежей человеческого сознания / пер. с англ. О. Цветковой. 2-е изд. М.: Институт трансперсональной психологии / САТТВА, 2000.

20 См.: Чижевский А. Л. Я молнию у неба взял / Сост. А.В. Манакин. Калуга, 1994. С. 7.
Показательно, что поэтические шедевры Александра Леонидовича, подобно всем его работам, в том числе и научным, зачастую пронизаны приподнятым настроением, моральной элевацией, восторженностью, упоением интеллектуальными прозрениями. Подобными эмоциями проникнуты также многие философские и фантастические произведения Циолковского. Все указанные выше чувства, как считает Бёкк, свойственны человеку, переживающему опыт космического сознания.

Не только в отношении преходящих эмоций, но и в том, что касается устойчивых личных качеств, мало зависящих от настроения, Циолковский и Чижевский в целом соответствуют духовному складу, который канадский учёный полагал характерным для людей, предрасположенных к обретению космического озарения. Так, Константин Эдуардович и Александр Леонидович отличались горячим стремлением к добру и истине, а также недюжинным интеллектом.

Бёкк также подчёркивал, что у пережившего космический опыт человека пропадает страх смерти, ибо он чувствует вечность жизни Целого, к коему причастен. Между тем, идея бессмертия занимает важное место в творчестве калужских мыслителей.

Так, Циолковского заставила сосредоточиться на «свойствах бессмертной материи» в том числе и трагическая гибель сына, покончившего жизнь самоубийством. Константин Эдуардович полагает Вселенную одушевлённой и вечно живой, признавая основным её «гражданином» атом, который в строгом смысле этого слова чувствует всегда, но достаточно сильно - лишь оказавшись в мозге развитого существа. Периоды, которые он проводит вне такового, субъективно для него практически не существуют, ибо его чувствительность на протяжении этого времени слишком мала. После гибели человека (и любого другого существа) его атомы ожидает воплощение в высших существах, а до этого момента они ничего не ощущают, поэтому смерти для них нет. Как тут не вспомнить Эпикура!

Мировоззрение Чижевского также пронизано мыслью о бессмертии Вселенной и её одушевлённости: «Само наше существование говорит за то, что космос уже неисчислимое количество раз восстанавливал себя из самого себя, иначе он давно уже завершил [бы] путь своей жизни и умер. Космос не знает истощения, ему присуща вечная жизнь, обусловленная ритмом, отбиваемым колоссальным космическим маятником. Только одно колебание этого великого маятника заключает 


\section{Духовная реинкарнация}

всю бездну времени, исчисляемую нами от начала до конца мироздания, которое при следующем колебании начинает своё следующее возрождение и так - без конца» ${ }^{21}$. Александр Леонидович не приемлет страха смерти: «Мы - дети нашей МатериПрироды. Она хочет, чтобы мы были разумные, в конце концов поняли и полюбили бы её, ибо уже перестали бы бояться смерти» ${ }^{22}$.

Также заслуживает внимания то обстоятельство, что как у Бёкка, имевшего опыт космического сознания, так и у калужских мыслителей (наряду, впрочем, с другими космистами) присутствует представление об эволюции человечества, причём у всех троих авторов отмечается, что на определённом этапе развития мышление людей «космизируется». Подобное совпадение заставляет задуматься. Не объясняется ли оно причастностью к космическому сознанию, которое открывает некие истины, подлежащие затем осмыслению и рациональному обоснованию (при желании или необходимости)?

Наконец, согласно Бёкку, специфической чертой космического сознания является следующее обстоятельство: у человека, переживающего соответствующий опыт, пропадает чувство принадлежности самому себе, он теряет свою волю. В свете данного наблюдения канадского исследователя показательны как наличие у Циолковского диалектического учения о воле Вселенной, превалирующей над индивидуальной волей человека, которая является её частным проявлением, так и детерминистские воззрения Чижевского, утверждавшего: «Вера в метафизический догмат о свободе воли являлась одною из главных причин, тормозящих объективное исследование истории... Учёным пришлось признать, на основании достижений науки, отсутствие таковой даже в самых малейших и ничтожных поступках и выдвинуть детерминистическую точку зрения для объяснения сложнейших явлений в психической жизни человека» ${ }^{23}$. Быть может, опыт ощущения отсутствия собственной воли сыграл свою роль в формировании детерминистских воззрений космистов.

Итак, мы рассмотрели ряд аргументов, в совокупности позволяющих заключить, что предполо-

\footnotetext{
21 Чижевский А.Л. Основное начало мироздания. Система космоса. Проблемы / Сост. Л.Т. Энгельгардт // Духовное созерцание. 1997. №№ 1-2. С. 109.

22 Там же. С. 109.

23 Чижевский А.Л. Физические факторы исторического процесса. Калуга, 1924. С. 6.
}

жение о причастности Циолковского и Чижевского к космическому сознанию является весьма правдоподобным. Что же нового даёт нам признание друзей-мыслителей носителями космического сознания для оценки их религиозно-мистических идей?

Во-первых, многие типичные для Константина Эдуардовича и Александра Леонидовича представления могут иметь основанием опыт космического сознания, а не влияние различных внешних источников, обозначенных выше (восточная и христианская традиции, астрология и т. п.). Так, Циолковский, возможно, сформировал некоторые свои представления (об одушевлённости, целостности и божественности Вселенной, её бессмертии, воле и т.п.) именно в состоянии космического сознания, равно как и Чижевский (например, о вечной жизни космоса, пронизанного сакральной целостностью).

Во-вторых, если мы примем концепцию космической игры, связанную с представлениями о космическом сознании, то получим возможность снять некоторые противоречия в религиозных воззрениях Константина Эдуардовича, а также показать, что его расхождение с Александром Леонидовичем по ряду вопросов является в какой-то степени мнимым. Кроме того, эволюция Вселенной (Абсолюта, Бога) во взаимосвязи с человеческим разумом, как её описывали калужские космисты, подобна игре космоса, представленной в названной концепции.

Как мы помним, претендентами на звание Бога (или богов) у Циолковского оказывались сама эволюционирующая во взаимосвязи с порождённым ею разумом одушевлённая Вселенная, её причина, «высшие люди», а также другие безмерно превосходящие современного человека интеллектом и нравственностью существа. Казалось бы, мыслитель проявляет непоследовательность, приписывая божественность в разных работах различным объектам. Однако если мы принимаем концепцию космической игры (а тайны последней постигаются при обретении космического сознания, по-видимому, наличествовавшего у Циолковского, писавшего, кстати, об игре космоса), то противоречия снимаются.

Действительно, Брахман (первопричина) творит Вселенную, по сути тождественную Ему самому, ибо Он есть единственная реальность. Таким образом, Абсолют (Бог) есть и сама Вселенная, и её причина. Что касается высших индивидуальных сознаний, то они порождены Брахманом и лишь на иллюзорном уровне отличны от таково- 
го, причём по мере своего совершенствования всё более сливаются с Ним.

Принимая концепцию космической игры, мы также делаем шаг к сближению религиозно-мистических воззрений Циолковского и Чижевского. Так, в названную концепцию прекрасно вписываются как указанные выше представления Константина Эдуардовича, так и «новая астрология» и тотальный холизм Александра Леонидовича (ибо части Абсолюта обладают лишь иллюзорной самостоятельностью). Соответственно, можно считать, что Циолковский и Чижевский освещают различные стороны постигнутой ими реальности.

Важно отметить, что эволюция Вселенной (т. е. Абсолюта по преимуществу, ибо более всего оба калужских мыслителя тяготели к пантеизму) у Константина Эдуардовича и Александра Леонидовича во многом напоминает игру космоса в соответствующей концепции. Для Циолковского и Чижевского было характерно представление о развитии Вселенной во взаимосвязи с человеческим разумом «по спирали»: система «Космос-человек» проходит одни и те же этапы на всё более высоком уровне. Аналогично Брахман может возобновлять свою игру после воссоединения с ним иллюзорно отчуждённых объектов, постепенно усложняя её, но сохраняя основные стадии процесса. Таким образом, мы видим, что Константин Эдуардович и Александр Леонидович в новом контексте и современным языком излагают воззрения, разделявшиеся ещё в Древней Индии. Это наводит на мысль об общем источнике подобных воззрений, учитывая тот факт, что Чижевский не увлекался восточной философией.

В указанном выше ключе, в частности, интересно рассмотреть, по-видимому приписанную Александром Леонидовичем старшему другу, теорию космических эр ${ }^{24}$, которая так повествует о конечном воссоединении человека и мира: «Итогом космической эволюции станет слияние Космоса и человека в великое совершенство. Человечество и Космос станут равновеликими и сольются «в телепатическое состояние высокого порядка, которое будет всё знать и ничего не желать» (Чижевский, 1999)» ${ }^{25}$. Не напоминает ли данное описание о взаимоотношениях и свойствах Атмана и Брахмана?

24 См. по этому поводу: Захаров М.Л. Антропологические и антропокосмические воззрения А.Л. Чижевского (URL: http://vestnik.mstu.edu.ru/v11_4_n33/articles/23_zakhar.pdf. (дата обращения 06.02.14)).

25 Там же.
Подобных соответствий между теорией космических эр и концепцией космической игры можно найти немало. Однако этот поиск потребовал бы отдельного исследования, соответственно, ограничимся уже сказанным.

Признание источником мистических и религиозных прозрений калужских друзей-мыслителей космического сознания и рассмотрение их идей в контексте космической игры наталкивает на предположение об их призвании служить катализаторами процесса эволюции космоса, приобщая людей к сакральной реальности посредством научных и философских рассуждений.

Показательно, что сторонники учения Живой Этики и подобных ему течений мысли относят Циолковского и Чижевского к сонму носителей космического сознания и глашатаев Высшей Реальности. Так, в Музее имени Н.К. Рериха имеются бюсты Константина Эдуардовича и Александра Леонидовича работы А.Д. Леонова, являющиеся частями скульптурной композиции «Вестники Космической Эволюции».

Таким образом, рассмотрев религиозные и мистические прозрения Циолковского и Чижевского в контексте представлений о космическом сознании и концепции космической игры, мы можем сделать вывод о возможности наличия невербального источника их творческого вдохновения, по-новому оценить некоторые идеи и призвание калужских мыслителей.

«Еретические» идеи Константина Эдуардовича и Александра Леонидовича долго ждали своего часа. И вот он настал. Иначе и быть не могло, ведь забвение их откровений противоречило бы замыслу космической эволюции (или, иначе выражаясь, правилам игры Брахмана), которая создала разум человека для того, чтобы он познал и направил её, восстановив единство микро- и макрокосма.

В связи со сказанным выше невольно вспоминаются слова выдающегося австрийского писателя Стефана Цвейга, которыми я и хотела бы завершить настоящую статью: «Всякий фанатизм в конце концов загоняет сам себя в угол - в этом его судьба. Разум же, вечный и терпеливый в своём спокойствии разум, может ждать и не отступаться. Порой, когда другие неистовствуют в упоении, он вынужден умолкнуть и онеметь. Но время его приходит вновь - оно приходит всегда» ${ }^{26}$.

26 Цвейг С. Триумф и трагедия Эразма Роттердамского (URL: http://lib.rus.ec/b/194019/read. (дата обращения: 20.02.2014)). 


\section{Духовная реинкарнация}

\section{Список литературы:}

1. Алексеева В.И. Константин Циолковский: размышления о жизни // Дельфис. 2001. № 26(2). С. 24-28.

2. Алексеева В.И. Философия бессмертия К. Циолковского: истоки системы и возможности анализа // Общественные науки и современность. 2001. № 3. С. 177-187.

3. Арлазоров М.С. Циолковский. 3-е изд., перераб. и доп. М.: Молодая гвардия, 1967. 256 с.

4. Бёкк Р.М. Космическое сознание. Исследование эволюции человеческого разума / пер. с фр. М.: София, 2008. $448 \mathrm{c}$.

5. Библия. М.: Российское Библейское общество, 2007. 1326 c.

6. Буралков А.А. А.Л. Чижевский. Посланник Солнца на Земле. М.: КОНЕК-М, 2009. 296 с.

7. Воробьев Б.Н. Циолковский. М.: Молодая гвардия, 1940. 262 с.

8. Гагаев А.А., Скипетров В.П. Философия А.Л. Чижевского. Саранск, 1999. 285 с.

9. Гёте Эпиграммы // Венеция 1790, эпиграмма 54. (URL: http://coollib.net/b/197217/read. (дата обращения: 20.02.2014)).

10. Гиренок Ф.И. Русские космисты. Из цикла «Страницы истории отеч. филос. мысли». М.: Знание, 1990. $62 \mathrm{c}$.

11. Голованов Л.С. Сродство сердец и дум (URL: http://www.xpomo.com/rusograd/tch2/golovanov1.html. (дата обращения: 20.02.2014)).

12. Голованов Л.В. Чижевский А.Л. // БСЭ. 3-е изд. М.: Советская энциклопедия, 1978. Т. 29. С. 550-551.

13. Гроф С. Космическая игра. Исследование рубежей человеческого сознания / пер с англ. О. Цветковой. 2-е изд. М.: Институт трансперсональной психологии / САТТВА, 2000. 256 с.

14. Гуревич П.С. Основы философии: учебное пособие. М.: Кнорус, 2011. 480 с.

15. Гуревич П.С. Философия человека. Ч. 1. М.: ИФ РАН, 1999. 221 с.

16. Гуревич П.С. Философия человека. Ч. 2. М.: ИФ РАН, 2001. 209 с.

17. Дёмин В.Н. Циолковский. М.: Молодая гвардия, 2005. 336 с.

18. Ермолаева В.Е., Ермолаев И.А. Философия великой личности. М.: Север, 2007. 184 с.

19. Желнина Т.Н. Воспоминания А. Л. Чижевского как источник для изучения биографии К.Э. Циолковского. Труды XXIV-XXV чтений, посвященныX разработке научного наследия и развитию идей К.Э. Циолковского (Калуга, 1989, 1990 гг.). М.: ИИЕТ АН СССР, 1991.

20. Захаров М.Л. Антропологические и антропокосмические воззрения А.Л. Чижевского (URL: http:// vestnik.mstu.edu.ru/v11_4_n33/articles/23_zakhar.pdf/ (дата обращения: 06.02.2014)).

21. Захаров М.Л. Философские идеи А.Л. Чижевского. Дисс. ... канд. философ. наук. Мурманск, 2006. 145 с.

22. Ионова T.A. Философско-антропологические идеи русского космизма XX века: историко-философский анализ. Дисс. ... канд. филос. наук. М., 1999. 162 с.

23. Казютинский В.В. Космическая философия К.Э. Циолковского: за и против // Земля и Вселенная. 2003. № 4. C. 43-54.

24. Мельников Л.Н. Калужский мечтатель (К 150-летию со дня рождения К.Э. Циолковского (1857-1935)) // Дельфис. 2008. № 53(1). С. 37-43.

25. Назаров Г.А. Чижевский А.Л. // Москва: Энциклопедия. М.: Советская энциклопедия, 1980. С. 658.

26. Прасолова Е.Л. Жить гению в цепях не надлежит... Докум. лит.-драм. композиция о счастье и трагедии судьбы «Леонардо да Винчи XX в.», основоположника гелиобиологии, почет. профессора и академика многих науч. учреждений зарубеж. стран, художника-пейзажиста и поэта А.Л. Чижевского (1897-1964 гг.). Калуга, 1993. 63 с.

27. Русский космизм: Антология философской мысли / сост. С.Г. Семенова, А.Г. Гачева. Вступ. ст.: С.Г. Гачева; предисл.: С.Г. Семенова; примеч.: А.Г. Гачева. М.: Педагогика: Пресс, 1993. 232 с.

28. Терехов С.В. Эволюционные идеи в естественнонаучном направлении русского космизма (К.Э. Циолковский, А.Л. Чижевский, В.И. Вернадский). Орел: ГОУ ВПО «ОГУ», 2011. 152 с.

29. Томилин К.А. Вокруг трепещет пульс Вселенной: А. Чижевский (URL: http://ihst.ru/personal/tomilin/ papers/chijevsky.htm. (дата обращения: 06.02.2014)).

30. Уроки Чижевского: метод. пособие / сост. О.В. Панфёрова, Е.Л. Прасолова. Калуга: Гриф, 2002. 205 с.

31. Философия: Энциклопедический словарь / под ред. А.А. Ивина. М.: Гардарики, 2004. 


\section{Психология и психотехника 3(66) • 2014}

32. Цвейг С. Триумф и трагедия Эразма Роттердамского (URL: http://lib.rus.ec/b/194019/read. (дата обращения: 20.02.2014)).

33. Циолковский К.Э. Грёзы о Земле и небе. Научно-фантастические произведения. Тула: Приокское книжное издательство, 1986. 264 с.

34. Ц Циолковский К.Э. Евангелие от Купалы. М.: Самообразование, 2003. 256 с.

35. Циолковский К.Э. Исследование мировых пространств реактивными приборами (1911-1912) // Циолковский К.Э. Избранные труды. М.: Академия наук СССР, 1962. С. 167-219.

36. Ц Циолковский К.Э. Космическая философия. М.: Сфера, 2004. 496 с.

37. Циолковский К.Э. Миражи будущего общественного устройства. М.: Самообразование, 2006. 352 c.

38. Циолковский К.Э. Приключения Атома: повесть. М.: Луч, 2009. 112 с.

39. Циолковский К.Э. Происхождение музыки и её сущность // Арх. АН СССР. Ф. 555. Оп. 1. Ед. хр. 472.

40. Циолковский К.Э. Путь к звёздам. Сборник научно-фантастических произведений. М.: Изд-во АН СССР, 1960. 358 с.

41. Ц Циолковский К.Э. Развитие тела и души // Арх. АН СССР. Ф. 555. Оп. 1. Ед. хр. 375.

42. Ццолковский К.Э. Щит научной веры. Сборник статей. Описание с позиций монизма Вселенной и развития общества. М.: Самообразование, 2007. 207 с.

43. Циолковский К.Э. Этика или естественные основы нравственности (1902-1903) // Арх. АН СССР. Ф. 555. Оп. 1. № 372.

44. Чижевский А.Л. В науке я прослыл поэтом: сборник стихов / сост. Л.Т. Энгельгардт. Калуга: Золотая аллея, 1996. $271 \mathrm{c.}$

45. Чижевский А.Л. В ритме Солнца. М.: Наука, 1969. 112 с.

46. Чижевский А.Л. Вся жизнь. М.: Советская Россия, 1974. 208 с.

47. Чижевский А.Л. Земля в объятиях Солнца. М.: Эксмо, 2004. 928 с.

48. Чижевский А.Л. Земное эхо солнечных бурь. М.: Мысль, 1976. 367 с.

49. Чижевский А.Л. Космический пульс жизни: Земля в объятиях Солнца. Гелиотараксия / Сост., вступит. статья, комментарии, подбор ил. Л.В. Голованова. М.: Мысль, 1995. 767 с.

50. Чижевский А.Л. На берегу Вселенной. Воспоминания о К.Э. Циолковском. М.: Айрис-пресс, 2007. 448 с.

51. Чижевский А.Л. Основное начало мироздания. Система космоса. Проблемы / сост. Л.Т. Энгельгардт // Духовное созерцание. 1997. №№ 1-2. С. 105-149; №№ 3-4. С. 85-113.

52. Чижевский А.Л. Стихотворения / Вступ. ст., сост. и подг. текстов В.И. Безъязычного. М.: Современник, 1987. 238 c.

53. Чижевский А.Л. Физические факторы исторического процесса. Калуга, 1924; репринт 1991. 72 с.

54. Чижевский А.Л. К.Э. Циолковский, А.Л. Чижевский. Калужские страницы русских космистов. Калуга: Гриф, 2007. 264 с.

55. Чижевский А.Л. Электронная теория и генезис форм // Арх. РАН. Ф. 1703. Оп. 1. Д. 2.

56. Чижевский А.Л. Я молнию у неба взял / Сост. А.В. Манакин. Калуга, 1994. 73 с.

57. Шапошникова Л.В. И я зажёг этот огонь // Великое путешествие. Кн. 3. Вселенная Мастера. М., 2005. С. 397-495.

58. Ягодинский В.Н. Александр Леонидович Чижевский. 1897-1964. М.: Наука, 1987. 304 с.

\section{References (transliteration):}

1. Alekseeva V.I. Konstantin Tsiolkovskii: razmyshleniya o zhizni // Del'fis. 2001. № 26(2). S. 24-28.

2. Alekseeva V.I. Filosofiya bessmertiya K. Tsiolkovskogo: istoki sistemy i vozmozhnosti analiza. Obshchestvennye nauki i sovremennost', 2001. № 3. S. 177-187.

3. Arlazorov M.S. Tsiolkovskii. 3-e izd., pererab. i dop. M.: Molodaya gvardiya, 1967. 256 s.

4. Bekk R.M. Kosmicheskoe soznanie. Issledovanie evolyutsii chelovecheskogo razuma / per. s fr. M.: Sofiya, 2008. $448 \mathrm{~s}$.

5. $\quad$ Bibliya. M.: Rossiiskoe Bibleiskoe obshchestvo, 2007.1326 s.

6. Buralkov A.A. A.L. Chizhevskii. Poslannik Solntsa na Zemle. M.: KONEK-M, 2009. 296 s.

7. Vorob'ev B. . Tsiolkovskii. M.: Molodaya gvardiya, 1940. $262 \mathrm{~s}$. 


\section{Духовная реинкарнация}

8. $\quad$ Gagaev A.A., Skipetrov V.P. Filosofiya A.L. Chizhevskogo. Saransk, 1999. 285 s.

9. Gete Epigrammy // Venetsiya 1790, epigramma 54. (URL: http://coollib.net/b/197217/read. (data obrashcheniya: 20.02.2014)).

10. Girenok F.I. Russkie kosmisty. Iz tsikla «Stranitsy istorii otech. filos. mysli». M.: Znanie, 1990. 62 s.

11. Golovanov L.S. Srodstvo serdets i dum (URL: http://www.xpomo.com/rusograd/tch2/golovanov1.html. (data obrashcheniya: 20.02.2014)).

12. Golovanov L.V. Chizhevskii A.L. // BSE. 3-e izd. M.: Sovetskaya entsiklopediya, 1978. T. 29. S. 550-551.

13. Grof S. Kosmicheskaya igra. Issledovanie rubezhei chelovecheskogo soznaniya / per s angl. O. Tsvetkovoi. 2-e izd. M.: Institut transpersonal'noi psikhologii / SATTVA, 2000. $256 \mathrm{s.}$

14. Gurevich P.S. Osnovy filosofii: uchebnoe posobie. M.: Knorus, 2011. $480 \mathrm{~s}$.

15. Gurevich P.S. Filosofiya cheloveka. Ch. 1. M.: IF RAN, 1999. 221 s.

16. Gurevich P.S. Filosofiya cheloveka. Ch. 2. M.: IF RAN, 2001. 209 s.

17. Demin V.N. Tsiolkovskii. M.: Molodaya gvardiya, 2005. $336 \mathrm{s.}$

18. Ermolaeva V.E., Ermolaev I.A. Filosofiya velikoi lichnosti. Sever, 2007. 184 s.

19. Zhelnina T.N. Vospominaniya A.L. Chizhevskogo kak istochnik dlya izucheniya biografii K.E. Tsiolkovskogo. Trudy XXIV-XXV chtenii, posvyashchennykh razrabotke nauchnogo naslediya i razvitiyu idei K. E. Tsiolkovskogo (Kaluga, 1989, 1990 gg.). M.: IIET AN SSSR, 1991.

20. Zakharov M.L. Antropologicheskie i antropokosmicheskie vozzreniya A.L. Chizhevskogo. (URL: http:// vestnik.mstu.edu.ru/v11_4_n33/articles/23_zakhar.pdf/ (data obrashcheniya: 06.02.2014)).

21. Zakharov M.L. Filosofskie idei A. L. Chizhevskogo: diss. ... kand. filosof. nauk. Murmansk, 2006. 145 c.

22. Ionova T.A. Filosofsko-antropologicheskie idei russkogo kosmizma XX veka: istoriko-filosofskii analiz. Diss.... kand. filosof. nauk. M., 1999. 162 c.

23. Kazyutinskii V.V. Kosmicheskaya filosofiya K. E. Tsiolkovskogo: za i protiv // Zemlya i Vselennaya. 2003. № 4. S. 43-54.

24. Mel'nikov L.N. Kaluzhskii mechtatel' (K 150-letiyu so dnya rozhdeniya K.E. Tsiolkovskogo (1857-1935)) // Del'fis. 2008. № 53(1). S. 37-43.

25. Nazarov G.A. Chizhevskii A.L. // Moskva: Entsiklopediya. M.: Sovetskaya entsiklopediya, 1980. S. 658.

26. Prasolova E.L. Zhit' geniyu v tsepyakh ne nadlezhit... Dokum. lit.-dram. kompozitsiya o schast'e i tragedii sud'by «Leonardo da Vinchi XX v.», osnovopolozhnika geliobiologii, pochet. professora i akademika mnogikh nauch. uchrezhdenii zarubezh. stran, khudozhnika-peizazhista i poeta A. L. Chizhevskogo (1897-1964 gg.). Kaluga, 1993. $63 \mathrm{~s}$.

27. Russkii kosmizm: Antologiya filosofskoi mysli / sost. S.G. Semenova, A.G. Gacheva. Vstup. st.: S.G. Gacheva; predisl.: S.G. Semenova; primech.: A.G. Gacheva. M.: Pedagogika: Press, 1993. 232 s.

28. Terekhov S.V. Evolyutsionnye idei v estestvennonauchnom napravlenii russkogo kosmizma (K.E. Tsiolkovskii, A.L. Chizhevskii, V.I. Vernadskii). Orel: GOU VPO «OGU», 2011.152 s.

29. Tomilin K.A. Vokrug trepeshchet pul's Vselennoi: A. Chizhevskii (URL: http://ihst.ru/personal/tomilin/ papers/chijevsky.htm. (data obrashcheniya: 06.02.2014)).

30. Uroki Chizhevskogo: metod. posobie / sost. O.V. Panferova, E.L. Prasolova. Kaluga: Grif, 2002. 205 s.

31. Filosofiya: Entsiklopedicheskii slovar' / pod red. A.A. Ivina. M.: Gardariki, 2004.

32. Tsveig S. Triumf i tragediya Erazma Rotterdamskogo (URL: http://lib.rus.ec/b/194019/read. (data obrashcheniya: 20.02.2014)).

33. Tsiolkovskii K.E. Grezy o Zemle i nebe. Nauchno-fantasticheskie proizvedeniya. Tula: Priokskoe knizhnoe izdatel'stvo, 1986. $264 \mathrm{~s}$.

34. Tsiolkovskii K.E. Evangelie ot Kupaly. M.: Samoobrazovanie, 2003. 256 s.

35. Tsiolkovskii K.E. Issledovanie mirovykh prostranstv reaktivnymi priborami (1911-1912) // Izbrannye trudy. M.: Akademiya nauk SSSR, 1962. S. 167-219.

36. Tsiolkovskii K.E. Kosmicheskaya filosofiya. M.: Sfera, 2004. $496 \mathrm{~s}$.

37. Tsiolkovskii K.E. Mirazhi budushchego obshchestvennogo ustroistva. M.: Samoobrazovanie, 2006. 352 s.

38. Tsiolkovskii K.E. Priklyucheniya Atoma: povest'. M.: Luch, 2009. 112 s.

39. Tsiolkovskii K.E. Proiskhozhdenie muzyki i ee sushchnost' // Arkh. AN SSSR. F. 555. Op. 1. Ed. khr. 472.

40. Tsiolkovskii K.E. Put' k zvezdam. Sbornik nauchno-fantasticheskikh proizvedenii. M.: Izd-vo AN SSSR, 1960. $358 \mathrm{~s}$. 
41. Tsiolkovskii K.E. Razvitie tela i dushi // Arkh. AN SSSR. F. 555. Op. 1. Ed. khr. 375.

42. Tsiolkovskii K.E. Shchit nauchnoi very. Sbornik statei. Opisanie s pozitsii monizma Vselennoi i razvitiya obshchestva. M.: Samoobrazovanie, 2007. 207 s.

43. Tsiolkovskii K.E. Etika ili estestvennye osnovy nravstvennosti (1902-1903) // Arkh. AN SSSR. F. 555. Op. 1. № 372 .

44. Chizhevskii A.L. V nauke ya proslyl poetom: sbornik stikhov / sost. L.T. Engel'gardt. Kaluga: Zolotaya alleya, 1996. $271 \mathrm{~s}$.

45. Chizhevskii, A.L. V ritme Solntsa. M.: Nauka, 1969.112 s.

46. Chizhevskii A.L. Vsya zhizn'. M.: Sovetskaya Rossiya, 1974. 208 s.

47. Chizhevskii A.L. Zemlya v ob"yatiyakh Solntsa. M.: Eksmo, 2004. 928 s.

48. Chizhevskii A.L. Zemnoe ekho solnechnykh bur'. M.: Mysl', 1976. 367 s.

49. Chizhevskii A.L. Kosmicheskii pul's zhizni: Zemlya v ob"yatiyakh Solntsa. Geliotaraksiya / Sostavl., vstupit. stat'ya, kommentarii, podbor il. L.V. Golovanova. M.: Mysl', 1995. 767 s.

50. Chizhevskii A.L. Na beregu Vselennoi. Vospominaniya o K.E. Tsiolkovskom. M.: Airis-press, 2007. 448 s.

51. Chizhevskii A.L. Osnovnoe nachalo mirozdaniya. Sistema kosmosa. Problemy / sost. L.T. Engel'gardt // Dukhovnoe sozertsanie. 1997. №№ 1-2. S. 105-149; №№ 3-4. S. 85-113.

52. Chizhevskii A.L. Stikhotvoreniya // Vstup. st., sost. i podg. tekstov V.I. Bez"yazychnogo. M.: Sovremennik, 1987. 238 s.

53. Chizhevskii A.L. Fizicheskie faktory istoricheskogo protsessa. Kaluga, 1924; reprint $1991.72 \mathrm{~s}$.

54. Chizhevskii A.L. K.E. Tsiolkovskii, A.L. Chizhevskii. Kaluzhskie stranitsy russkikh kosmistov. Kaluga: Grif, 2007. $264 \mathrm{~s}$.

55. Chizhevskii A.L. Elektronnaya teoriya i genezis form // Arkh. RAN. F. 1703. Op. 1. D. 2.

56. Chizhevskii A.L. Ya molniyu u neba vzyal. / Sost. A.V. Manakin. Kaluga, 1994. 73 s.

57. Shaposhnikova L.V. I ya zazheg etot ogon' // Velikoe puteshestvie. Kn. 3. Vselennaya Mastera. M., 2005. S. 397-495.

58. Yagodinskii V.N. Aleksandr Leonidovich Chizhevskii. 1897-1964. M.: Nauka, 1987. 304 s. 